\title{
Severity of Climate Induced Drought and its Impact on Migration: A Study of Ramechhap District, Nepal
}

\author{
N. Joshi" and R. Dongol \\ Nepal Engineering College-Centre for Postgraduate Studies \\ Pokhara University \\ Nepal
}

\begin{abstract}
Drought, a slow phenomenon, increases severity in agriculture that is directly or indirectly linked with water. Livelihood of rural people in Nepal mainly depends on agriculture, therefore, drought either results in diversification of livelihood or most likely increase poverty. Thus, severity of drought leading to migration (permanent and seasonal) as a common livelihood strategy was studied in Pakarbas (Khadadevi Municipality) and Chisapani (Manthali Municipality) of Ramechhap District in Nepal. From the trend analysis of recorded data, the total annual rainfall was found to be decreasing whereas May, June and July were found to be the hottest months observed in temperature trend and the year 2009 had the maximum recorded temperature $\left(32.6{ }^{\circ} \mathrm{C}\right)$. Similarly, the number of dry months was observed to have slow but increasing trend. For drought assessment and mapping, remote sensing analysis was adopted for three years using LANDSAT 4 and 5 TM for 2006 and 2009 and LANDSAT 8 OLI and TIRS for 2016 using Drought Exposure Index as Normalized Difference Vegetation Index, Water Stress Index as Normalized Difference Water Index and Agricultural Drought Severity as Normalized Difference Drought Index. The key informant interviewers revealed that during 10 years of period, the major spring sources, river/streams, irrigation canal have been dried completely which compelled them to migrate to other areas where they could carry out agriculture activities. In conclusion, the major reason for seasonal migration was mainly, insufficient year-round sources for livelihood. Not all migrants were able to raise their income for household but at least were able to minimize risks for livelihoods.
\end{abstract}

Keywords: Drought, drought indices, livelihood, migration

\section{INTRODUCTION}

Nepal is warming at significantly higher rate compared to the global average of $0.74{ }^{\circ} \mathrm{C}$, recorded in the twentieth century (IPCC, 2007). Climate change leads to water stress and has become one of the most pressing environmental problems around the globe. Analyzing the temperature data from 49 stations in Nepal for the period from 1971- 1994, Shrestha et al. (1999) revealed that the warming trends after 1977 ranging from 0.068 to $0.128{ }^{\circ} \mathrm{C}$ per year in most of the Middle Mountain and Himalayan regions. The Siwalik and Terai (southern plains) regions show warming trends in less than $0.038{ }^{\circ} \mathrm{C}$ per year. Frequent drought, rise in temperature, shortening of monsoon season with high intensity rainfall, severe floods, landslides and mixed effects on agriculture and biodiversity are experienced by Nepal due to climate change (Mehta and Shah, 2012). Comprehensive assessment of water management in

* Corresponding author: neekitajoshi2014@gmail.com 
agriculture has revealed that one in three people are already facing water shortages (IPCC, 2007). Therefore, general objective of the study was to evaluate the impacts of agricultural drought on livelihood leading to migration of people in the selected two Village Development Committees (VDCs) of Ramechhap District, Nepal.

\section{Study area}

\section{METHODOLOGY}

Ramechhap District looks like a plough in shape occupying $1564.33 \mathrm{~km}^{2}$ land area, spreading from $27^{\circ} 28^{\prime} \mathrm{N}$ to $27^{\circ} 50^{\prime} \mathrm{N}$ latitude and from $85^{\circ} 50^{\prime}$ to $86^{\circ} 35^{\prime}$ East longitude. Ramechhap District is surrounded by Okhaladhunga and Solukhumbu Districts on the east, Kavrepalanchok District on the west, Dolakha and Sindhupalchowk Districts on the north and Sindhuli District on the south. The lowest point of the district is Kolonjorghat, situated at $439 \mathrm{~m}$ from mean sea level (msl) and the highest point is Numbur Chuli peak situated at $6,958 \mathrm{~m}$ from msl. The average monsoon rainfall of Ramechhap is around $1315 \mathrm{~mm}$ and the average annual temperature is $17.4{ }^{\circ} \mathrm{C}$ (Climate-Data, 2016). Climate varies from subtropical to alpine and district is enclosed by three main rivers of Sapta Koshi River System namely Sun Koshi on the south west, Tama Koshi in the central and Likhu on the east. Although three major rivers of Sapta Koshi River System flow through Ramechhap, there is a very small fraction of land irrigated by these rivers and people residing on the edge of these rivers even face drinking and irrigation water scarcity due to drought and rugged geographic terrain (Shrestha et al., 2015).

The Figure 1 was prepared from the details given in Disaster Preparedness Report (DPR), Government of Nepal (GoN), 2011 of Ramechhap District. The Figure 1 shows the areas with dominant hazard types within Ramechhap District. Out of 55 Village Development

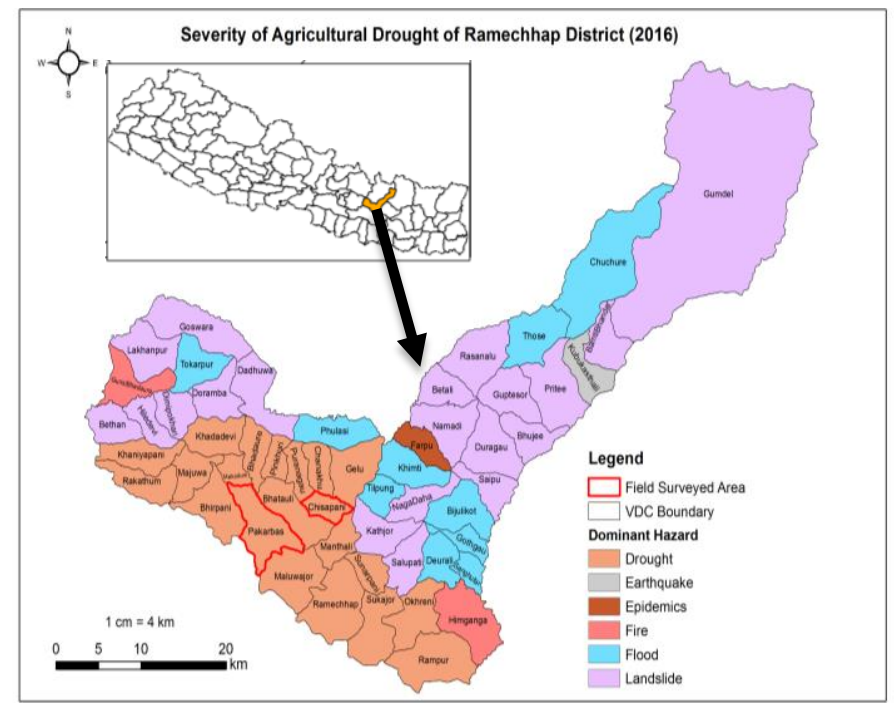

Figure 1. Dominant hazard map of Ramechhap District

Committees (VDCs) of the district, 21 VDCs fall under high level of drought. The areas enclosed by the red lines in the Figure 1 represent the study areas. 


\section{Satellite image analysis to derive drought indices}

Satellite-derived drought indices typically use observations in multispectral bands, each of which provides different information about surface conditions. Since droughts are naturally associated with vegetation state and cover; Vegetation Indices (VIs) are commonly used for this purpose (Tucker, 1979; Choudhary et al., 2012), utilizing data in the visible red (R), near infrared (NIR) and the shortwave infrared bands. Some drought indices are based on observations in the thermal infrared (TIR) spectral region, which conveys information about vegetation health and soil moisture status.

\section{Normalized Difference Vegetation Index as drought exposure index}

Satellite data processed into normalized difference vegetation indices (NDVI) can be used to indicate deficiencies in rainfall and portray meteorological and/or agricultural drought patterns both temporally and spatially, thus serving as an indicator of regional drought patterns (Erdenetuya et al., 2011). The most commonly used vegetation index is the normalized difference vegetation index (NDVI) and was first suggested by Tucker (1979) as an index of vegetation health and density. It varies in a range of -1 to +1 (Choudhary et al., 2012).

Normalized Difference Vegetation Index (NDVI) was calculated for 2006 and 2009 using Red and Near Infra-Red (NIR) bands of LANDSAT-4 and 5 TM; likewise NDVI for 2016 was calculated from LANDSAT 8 OLI and TIRS sensors. The index is based on the difference between the maximum absorption of radiation in Red as a result of chlorophyll pigments and the maximum reflectance in NIR spectral region as a result of leaf cellular structure (Tucker, 1979). The Eq. 01 was used to calculate the index.

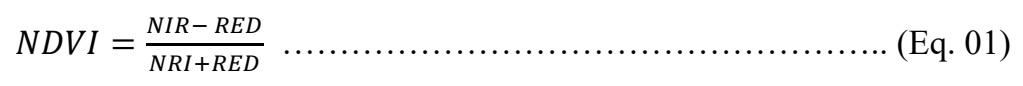

After calculation of NDVI using Eq. 01, for the major drought events (2006 and 2009) published in DPR and the news covered at different periods, a standard classification scheme was adopted with the break values in the histogram for drought exposure index. NDVI was adopted as a strong indicator for water stressed vegetation, agricultural drought assessment and monitoring. NDVI is a primary tool for interpretation of the impact of climatic/weather events (Choudhary, 2012).

\section{Normalized Difference Water Index as water stressed index}

Gu et al. (2008) found that Normalized Difference Water Index (NDWI) values exhibit a quicker response to drought conditions. NDWI using Short Wave Infra-Red (SWIR) band is very good in detecting water stressed conditions and is a good indicator to assess drought conditions. NDWI was calculated from the near-infrared (NIR) and Short Wave Infra -Red (SWIR) bands from LANDSAT- 4 and 5 TM (2006 and 2009) and LANDSAT 8 OLI and TIRS (2016) satellite images (Eq. 02).

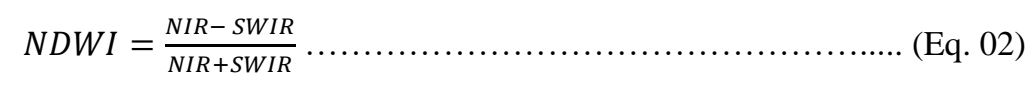

According to raster reclassification using Eq. 02 for all the three years, water stressed index was calculated using natural breaks (jenks) among several standard classification schemes 
and from the analysis southern area categorized as drought affected area by District Preparedness Report, GoN of Ramechhap District was found to be under high water stress.

\section{Normalized Difference Drought Index as Drought Severity Index}

Normalized Difference Drought Index (NDDI) developed by Gu et al. (2007) was used to assess drought severity. Analysis revealed that combining information from visible, near infrared, and shortwave infrared bands of satellite images can improve the sensitivity to drought severity. Therefore, normalized difference drought index (NDDI) has a stronger response in studying severity of drought and hence is a more sensitive indicator of drought (MODIS, 2016).

The Normalized Difference Drought Index (NDDI) combines information from both the NDWI and NDVI data derived from LANDSAT bands (Eq. 03) (MODIS, 2016).

$$
N D D I=\frac{N D V I-N D W I}{N D V I+N D W I}
$$

\section{Land Surface Temperature as an indicator of drought}

Land Surface Temperature (LST) derived from Thermal Infrared (TIR) band provides vital and useful information on the land surface and is widely implemented in formulating the energy and water budgets at the surface - atmosphere interface (Gutman, 1990 as cited in Karnieli et al., 2009). In this context, LST serves as a proxy for assessing evapotranspiration, vegetation water stress and soil moisture (Anderson et al., 2007 as cited in Karnieli et al., 2009). LST provides useful information about vegetation condition (Kogan, 1997).

The methodological flowchart in generating LST is shown in Figure 2.

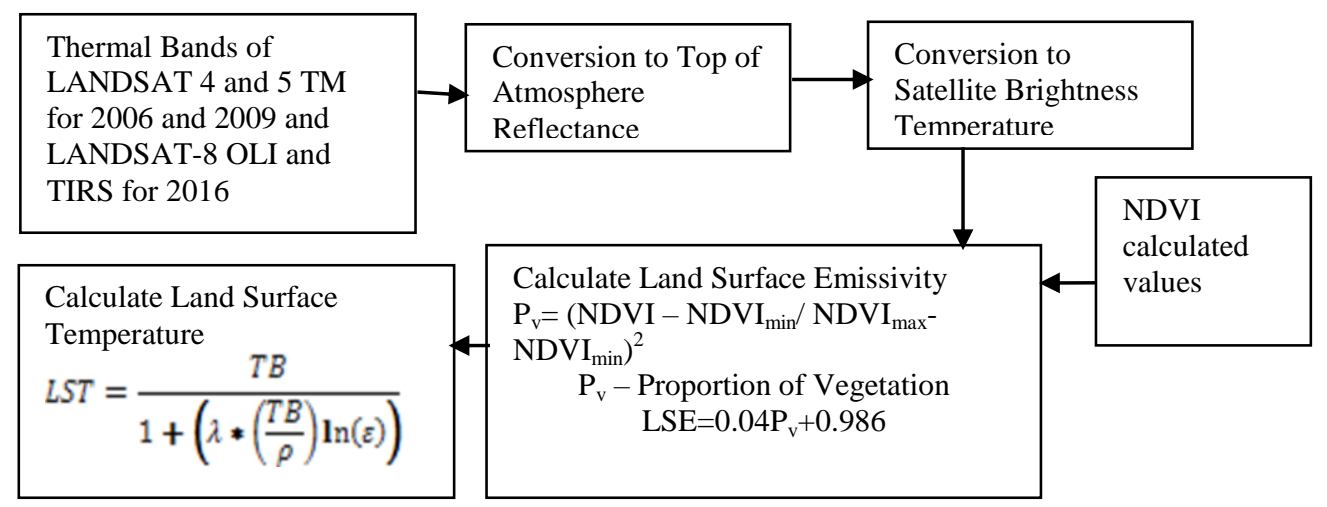

Figure 2. Flowchart of generation of land surface temperature

\section{Methodology framework}

First of all, the monthly temperature (2008 to 2015) and monthly rainfall data (1992 to 2015) of the representative meteorological station i.e. Manthali (station No. 1123) obtained from Department of Hydrology and Meteorology (DHM) were analyzed to assess the trend. Interpolated rainfall and temperature point data from DHM portal was used for mapping by 
Kriging method. Key Informant Interview (KII) with local people and experts in Ramechhap District was carried out to validate the output of the analysis. The methodological process adopted for this study is shown in Figure 3.

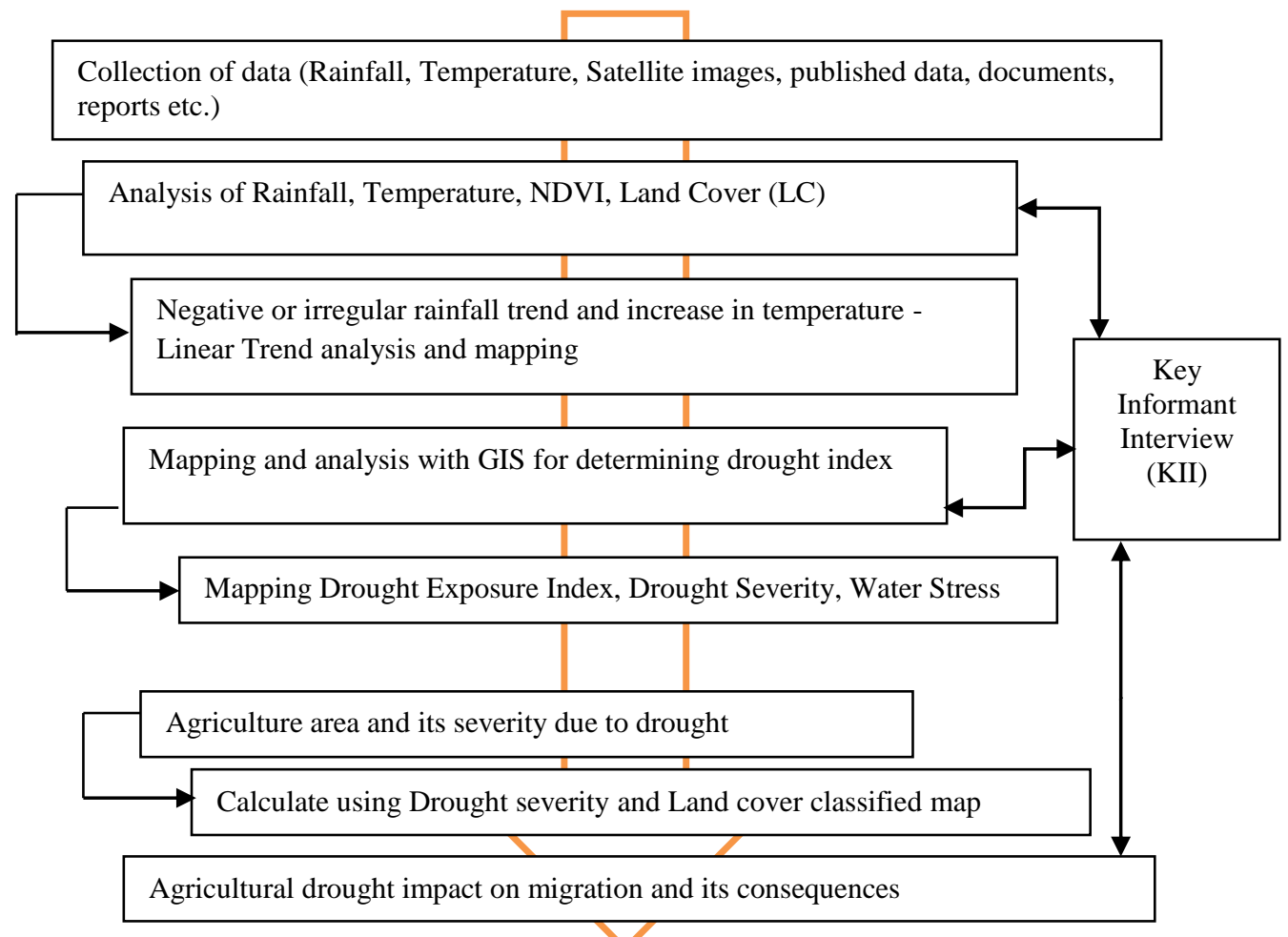

Figure 3. Methodological flow chart

\section{RESULTS AND DISCUSSION}

\section{Temperature trend}

The monthly maximum and minimum temperature data of Manthali station was available for only 8 years (2008-2015) (GoN, 2016). The maximum temperature data of few months were not available in three-year data (2008, 2010 and 2014); therefore, only five years of data were used for analyzing monthly maximum temperature trend. Similarly, monthly minimum temperature data of three year $(2008,2010$ and 2014) were not available that led to analyze only six years of data for monthly minimum temperature trend. Analysing monthly maximum temperature data shows that May, June and July are the hottest months during 2008-2015 period. The maximum temperature of $32.64{ }^{\circ} \mathrm{C}$ was recorded in 2009 , this year was one of the drought years as recorded in Disaster Preparedness Report (GoN, 2011). The minimum temperature has fluctuated in last 6 years and highest minimum temperature of $17.97^{\circ} \mathrm{C}$, recorded in 2009 .

Furthermore, from the field survey in Pakarbas and Chisapani, local residents also expressed that due to high temperature in 2009 , maize seeds had dried and could not germinate. Local 
farmers also experienced severe agricultural losses during 2014/2015 as a combination of no rainfall and high temperature. To further study the trend of Temperature in Ramechhap District, the spatial pattern of temperature (1980-2010) was mapped by interpolating $12 \mathrm{~km}$ X $12 \mathrm{~km}$ temperature grid data using geo-statistical method Kriging in ArcGIS and is shown in Figure 4.

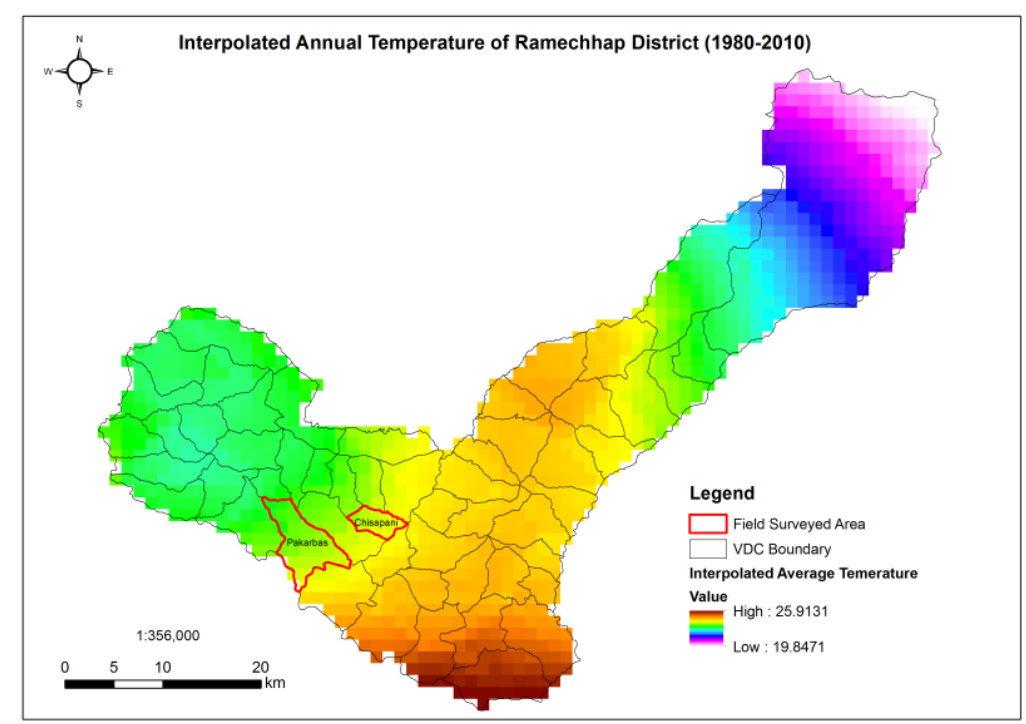

Figure 4. Interpolated average temperature map

Land Surface Temperature (LST) was also calculated using the thermal band of LANDSAT image for three years 2006, 2009 and 2016. The mean land surface temperature (LST) in Chisapani and Pakarbas are respectively $26.52{ }^{\circ} \mathrm{C}$ and $27.25{ }^{\circ} \mathrm{C}$ in $2016,36.23^{\circ} \mathrm{C}$ and $35.41^{\circ} \mathrm{C}$ in $2009 ; 14.34{ }^{\circ} \mathrm{C}$ and $12.73{ }^{\circ} \mathrm{C}$ in 2006 . Therefore, the highest mean LST in study area was in 2009. Among three years, the maximum LST $\left(43.37{ }^{\circ} \mathrm{C}\right)$ was resulted in Himganga with only one count, whereas in 2016 it was $38.45{ }^{\circ} \mathrm{C}$ (Those with only one count) as shown in Figure 5.

The key informants (experts and local people) also revealed that the dryness has significantly increased in last 10 years which has created more difficulties in agricultural practices and even uncertainty was prevailed during monsoon season. Since 5-6 years, they have been practicing dry paddy seedling bed (usually they practice this technique in dry soil) where there is less rainfall and usually they prepare paddy bed and wait for the rainy day for puddling. However, the rainfall had been very uncertain during past 5-6 years. Due to extreme hot climate, there was not enough moisture in soil required for maize seed germination resulting drying of seeds. Agricultural lands having optimum soil moisture is required for seed germination as well as for proper growth and production. However, during the field observations in this study area in 2017, dry and loose soil particles were seen in the field. 

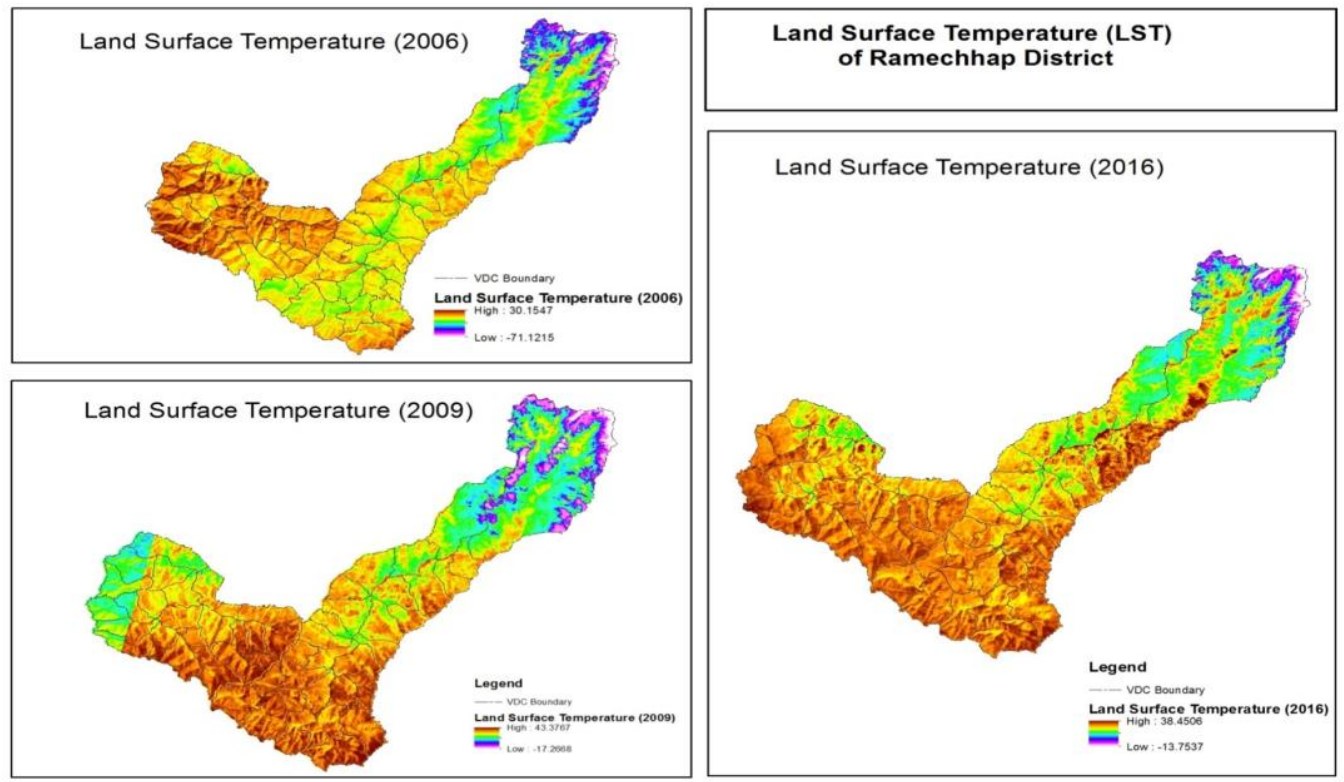

Figure 5. Land surface temperatures in 2006, 2009 and 2016

\section{Rainfall trend}

Available data of rainfall of Manthali station was analyzed to observe the rainfall trend over the past 22 years (from 1993 - 2015). In reference to CIAT (1999) and Farrow et al. (2005), months with rainfall less than $60 \mathrm{~mm}$ were considered "dry" months. Therefore, a plot of dry months was plotted to observe the trend of dry months. The number of dry months is increasing slowly but not significantly Figure $6,\left(R^{2}=0.0011\right)$. The maximum number of months with less than $60 \mathrm{~mm}$ rainfall (dry months) was 9 in 1996, 2008, 2010 and 2015 however, the maximum number of dry months (10 months) was observed in 1997. However, the dry months are not in succession due to unavailability of recorded data. The total annual rainfall in the study area is also in decreasing trend (Figure 7), however not significant $\left(R^{2}=0.182\right)$ for a duration of 22 years $(1993-2015)$.

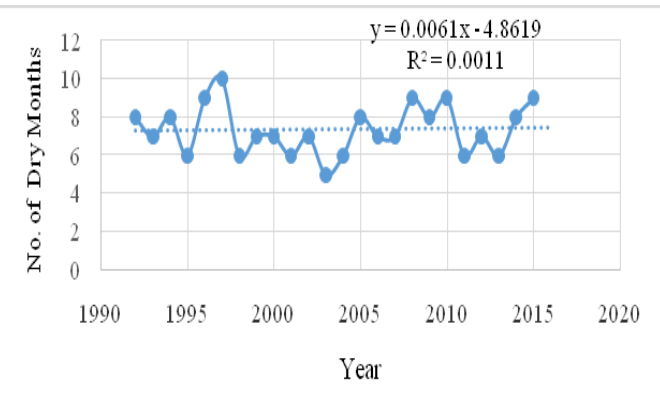

Figure 6. Months with less than $60 \mathrm{~mm}$ rainfall (Dry months) in Manthali station

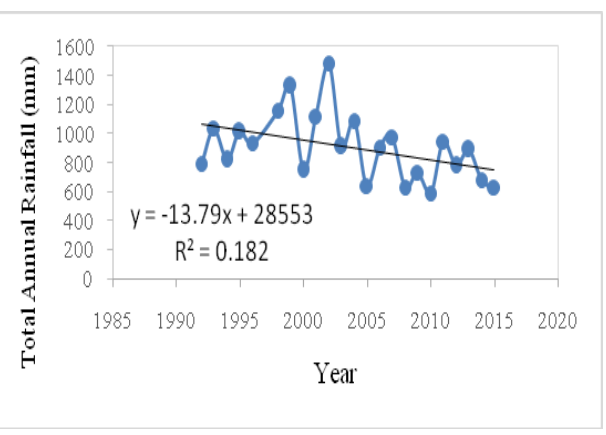

Figure 7. Total annual rainfall in Manthali Station 
The trend of total rainfall shows irregularity over the years at Manthali station. Least total rainfall $(195 \mathrm{~mm})$ was recorded in 1997. This year was excluded in Figure 10 as the rainfall data for four prominent months of monsoon (June to September) in 1997 was not available. Otherwise this could mislead the interpretation and analysis. The total amount of rainfall recorded in 2002 was $1483 \mathrm{~mm}$. Average annual rainfall in this district is recorded around $2020 \mathrm{~mm}$ (DADO, undated as cited in Thapa, 2012). From the trend analysis as shown in Figure 10 a decreasing trend of total annual rainfall was noted but is fluctuating in each consecutive year.

Based on the trend analysis (Figure 9) it can be concluded that number of months with minimum rainfall of $60 \mathrm{~mm}$ per year are increasing slightly but not significantly and total annual rainfall is irregular (Figure 10). The rainfall trend analysis in Ramechhap District was done by using the available data in DHM from 1993-2015 and point data (1980-2010) from the DHM portal was mapped by interpolating $12 \mathrm{~km} \mathrm{X} 12 \mathrm{~km}$ rainfall grid data using geostatistical method Kriging using ArcGIS. Interpolated annual rainfall was mapped as shown in Figure 11. The maximum mean interpolated annual rainfall was $3308.12 \mathrm{~mm}$ and minimum mean interpolated annual rainfall was 942.164 in Ramechhap District.

Additionally, field interviews were also supported that the rainfall in the study areas has been very erratic and indecisive since past 10 years. There has been noticeable shift in rainfall pattern which has ruthlessly affected the agricultural duration and cultivation time. In the year 2014/15, no rainfall till end of August had resulted observable impacts on the agricultural practices and crop production. During the field visits in 2017, it was observed that some of the farmers in Chisapani have started cultivating vegetables but due to inadequate rainfall farmers were not satisfied even from the vegetable production. In Pakarbas, families are staying in their old village with farming difficulties such as no or poor germination of paddy and maize seeds due to lack of rainfall and hot climate. The resultant of this was less food production which is hardly sufficient for three months. The problems of water fetching (which seek almost a whole day), low yield, and limited water sources and poor access and social conflict as a result of competition to reach water source for water collection and queuing for more than 45 minutes to fill a gagri of water put extra burden to these households. Such constraints had compelled them to search for other probable livelihood strategies, and migration is one of them.

\section{Drought Exposure Index}

The extent of negative deviation of NDVI from its long-term mean for a district or region, and the duration of continuous negative deviations are powerful indicators of drought magnitude and persistence (Thenkabali et al., 2004). NDVI being a strong indicator for vegetation exposed to drought, it was calculated and mapped using ArcGIS and Erdas imagine. Drought Exposure Index of 2016 is shown in Figure 8. The area exposed to drought was calculated for comparative analysis. A huge area (26231.07 ha) was exposed to very high drought in 2009 (Table 1), which also resonance with DPR, Ramechhap, 2011. Lower NDVI indicates more exposed to drought. The Exposure index ranged from 0.03 to 0.25 which was further classified using GIS. The thresholds for index were identified through a histogram in GIS which are as follows:

i. Very high exposed to drought [ $0.03-0.103]$;

iii. High exposed to drought [ $0.103-0.15]$;

v. Moderately exposed to drought [ $0.15-0.20]$; ii. Very less exposed to drought [ 0.20-0.25];

iv. Not Significant [ $>0.25$ ];

vi. Water Bodies/ Snow/ Glacier [ <0.03]; 
Table 1. Drought exposed area comparison

\begin{tabular}{lllll}
\hline $\begin{array}{l}\text { Drought Exposure Index } \\
\text { Very High Exposed }\end{array}$ & $\begin{array}{l}\text { Area in 2006 } \\
\text { (ha) }\end{array}$ & $\begin{array}{l}\text { Area in 2009 } \\
\text { (ha) }\end{array}$ & $\begin{array}{l}\text { Area in 2016 } \\
\text { (ha) }\end{array}$ \\
\hline $\begin{array}{l}\text { Vrought } \\
\text { High Exposed to Drought }\end{array}$ & 9295.47 & 26231.07 & 19050.93 \\
$\begin{array}{l}\text { Moderately Exposed } \\
\text { Drought }\end{array}$ & 22644.00 & 34504.61 & 41535.72 \\
$\begin{array}{l}\text { Less Exposed To drought } \\
\text { Not Significant }\end{array}$ & 45018.00 & 21319.94 & 44210.43 \\
$\begin{array}{l}\text { Water Bodies/ Snow/ Glacier } \\
\text { Total }\end{array}$ & $\begin{array}{l}42971.49 \\
22646.79\end{array}$ & 28780.05 & 30452.85 \\
\hline
\end{tabular}

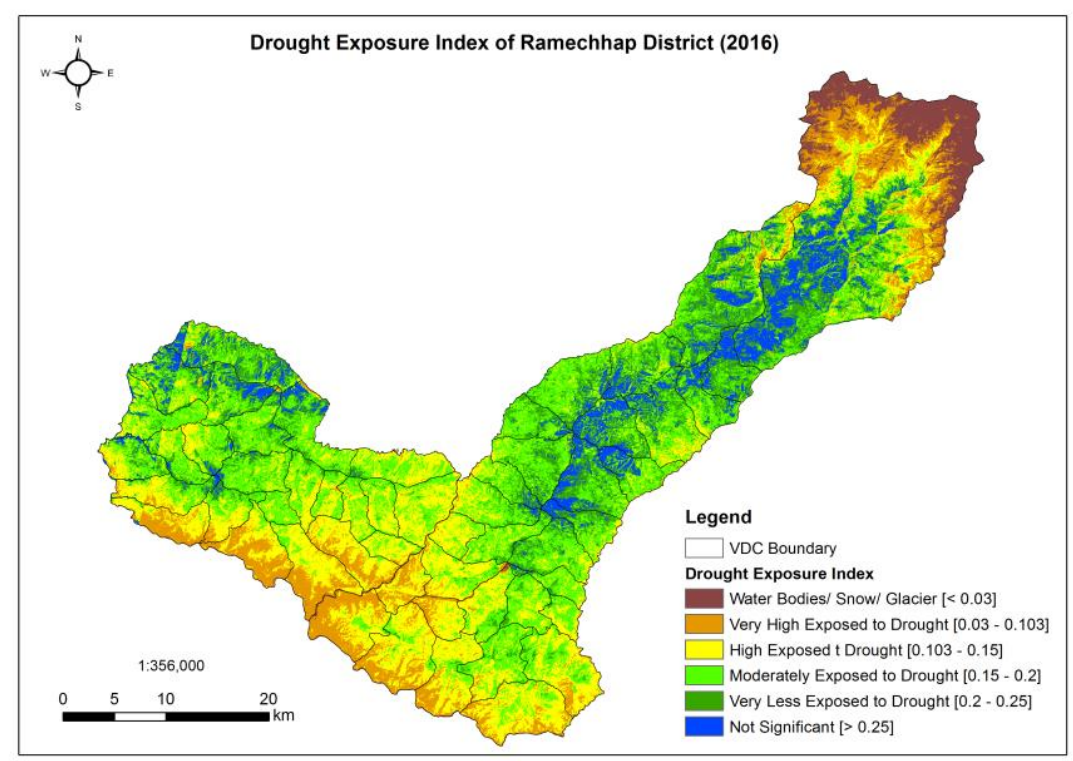

Figure 8. Drought Exposure Index mapping

\section{Correlation between NDVI-LST and NDVI-Rainfall}

A negative correlation of NDVI with respect to LST values for the years 2006, 2009 and 2016 was obtained (Figure 9). The correlation between LST and NDVI is - 0.9801 for 2016, -0.9945 for 2009 and -0.9579 for 2006 respectively. It can be clearly noted that both the parameters are inversely proportional to each other. When the temperature is greater, the NDVI value is lesser.

The decrease in soil moisture due to lack or untimely onset of rainfall along with the increased temperature causes the agricultural drought to be severe. If the precipitation is too much or too little and temperatures are too high for a prolonged period, these two climatic conditions prohibit vegetation growth. Therefore, in order to analyze the vegetation response to rainfall, regression analysis was done to develop a correlation between rainfall and NDVI. Scatter plot was used for the regression analysis of the interpolated rainfall data acquired 
from DHM portal and NDVI calculated from LANDSAT satellite data. The correlation resulted 0.97 and regression value $\mathrm{R}^{2}$ resulted 0.9422 which is almost equivalent to 1.00 as shown in Figure 9. Therefore, it illustrates a very strong relationship between the two variables rainfall and NDVI.

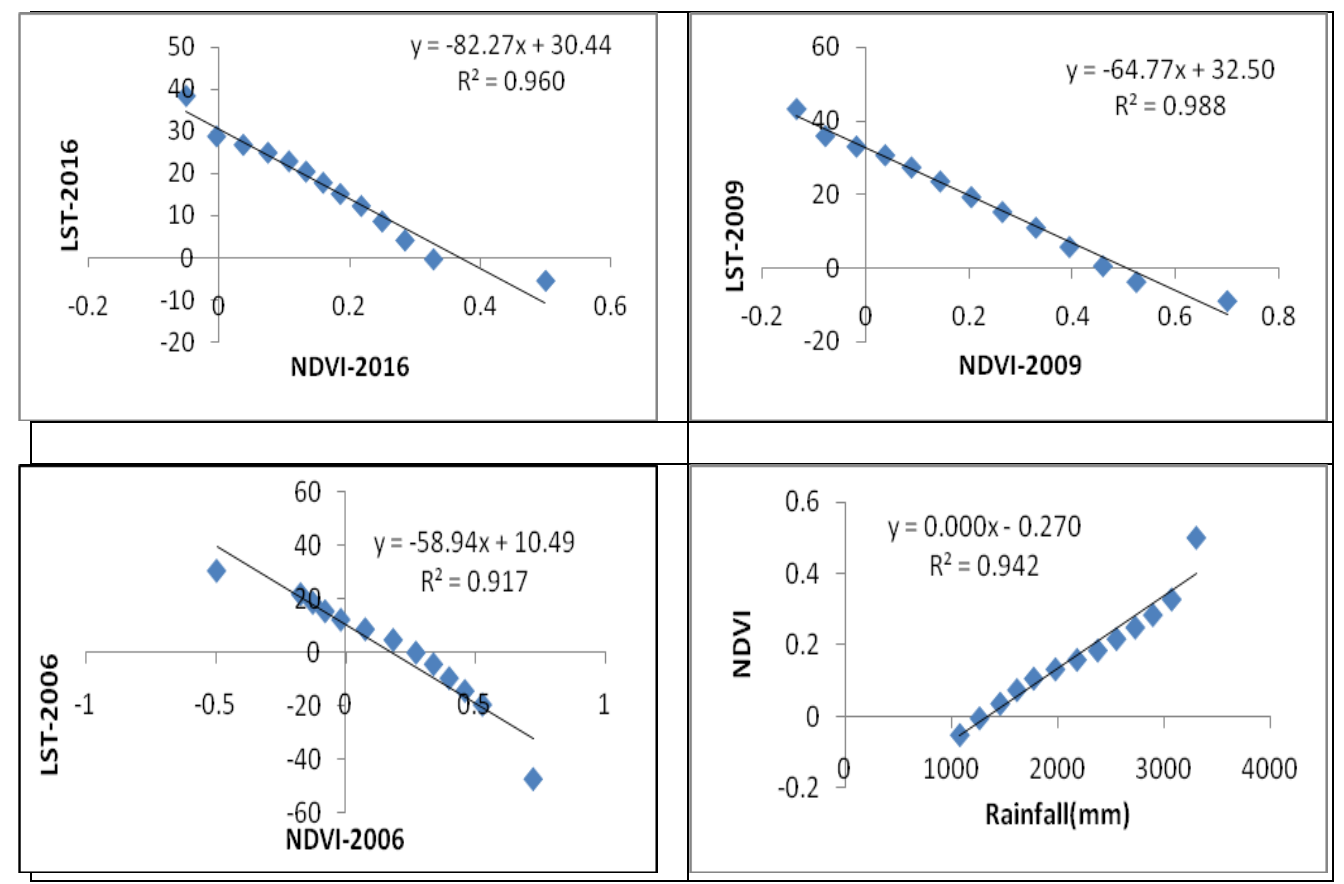

Figure 9. Correlation between NDVI - LST and NDVI - rainfall

\section{Trend analysis of drought with three-year comparison of NDVI}

The maximum NDVI is an indicator of the better plant growth. NDVI is very useful index for drought assessment as well as it is also useful in monitoring impact of climate on vegetation. Therefore, NDVI and LST calculated for 2006, 2009 and 2016 respectively were plotted for trend analyses which are illustrated in Figures 10 and 11. It is clearly seen that NDVI is in decreasing trend till 2016. The combination of NDVI and LST provides very useful information for agricultural drought monitoring and early warning system. Agricultural drought results in decline in productivity of crops due to irregularities of the rainfall as well as decrease in the soil moisture, which in turn directly affect the livelihood of people who solely depends on agriculture. Therefore, the trend analysis was done for year 2006, 2009 and 2016 which clearly reveals that maximum LST was found in 2009 which was an example of the extreme temperature event as per local respondents during field survey. Farmers also expressed that production of the maize crops were completely lost due to extremely hot temperatures in 2009. 


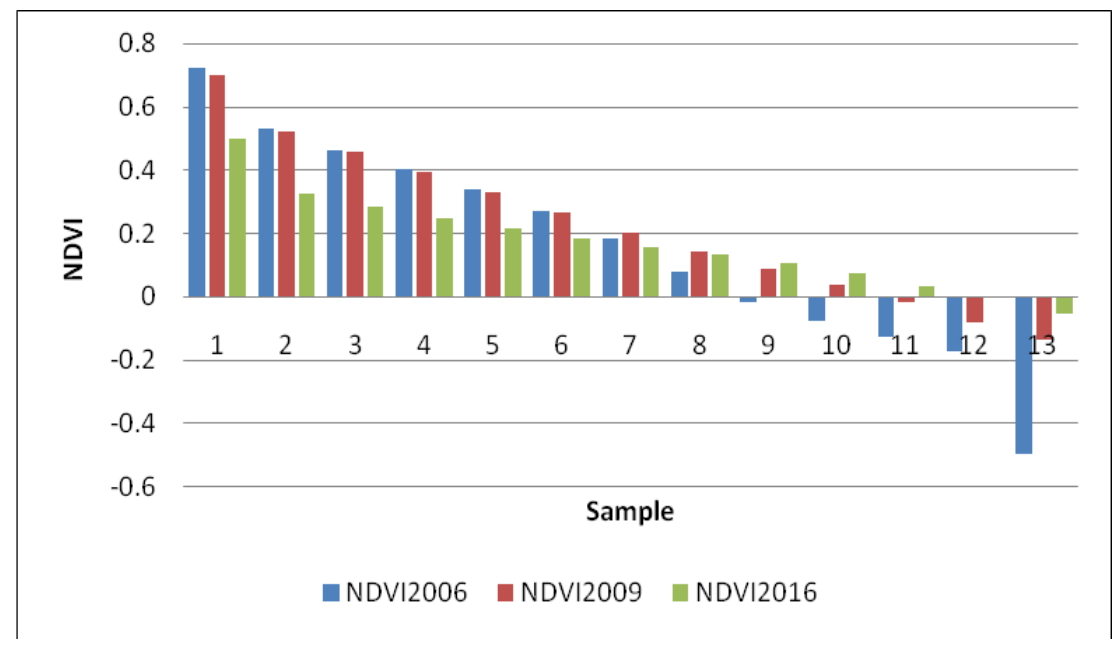

Figure 10. Year wise comparison of NDVI

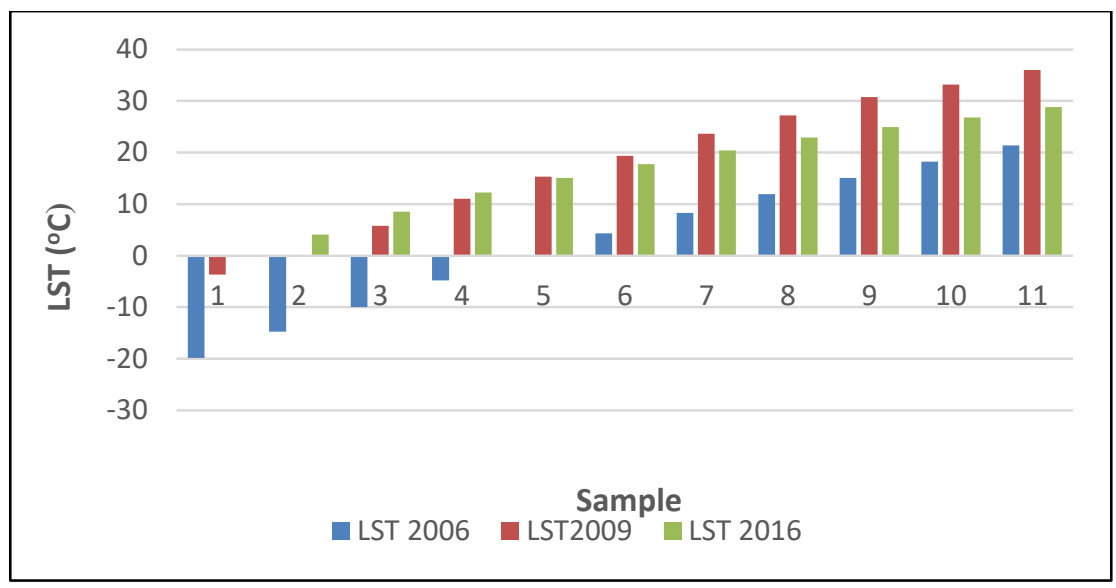

Figure 11. Year wise comparison of LST

\section{Drought severity map and agricultural drought severity}

Normalized Difference Drought Index (NDDI) incorporate visible, red and shortwave infrared bands hence; it has been considered for analyzing the severity of drought. Severity of drought determined and differentiated into five different classes as shown in Figure 12. This analysis was also useful for determining aerial extent of drought severity and it represents on the basis of each pixel. As per records (GoN, 2011) southern part of the district is more prone to drought and the result from this study also indicates that the severity is also very high in that part. For the assessment of Drought Severity, NDDI Index was used. The Severity index ranged from values less than -2 to values greater than 3 which were further classified using GIS. The thresholds used for index are as follows: 

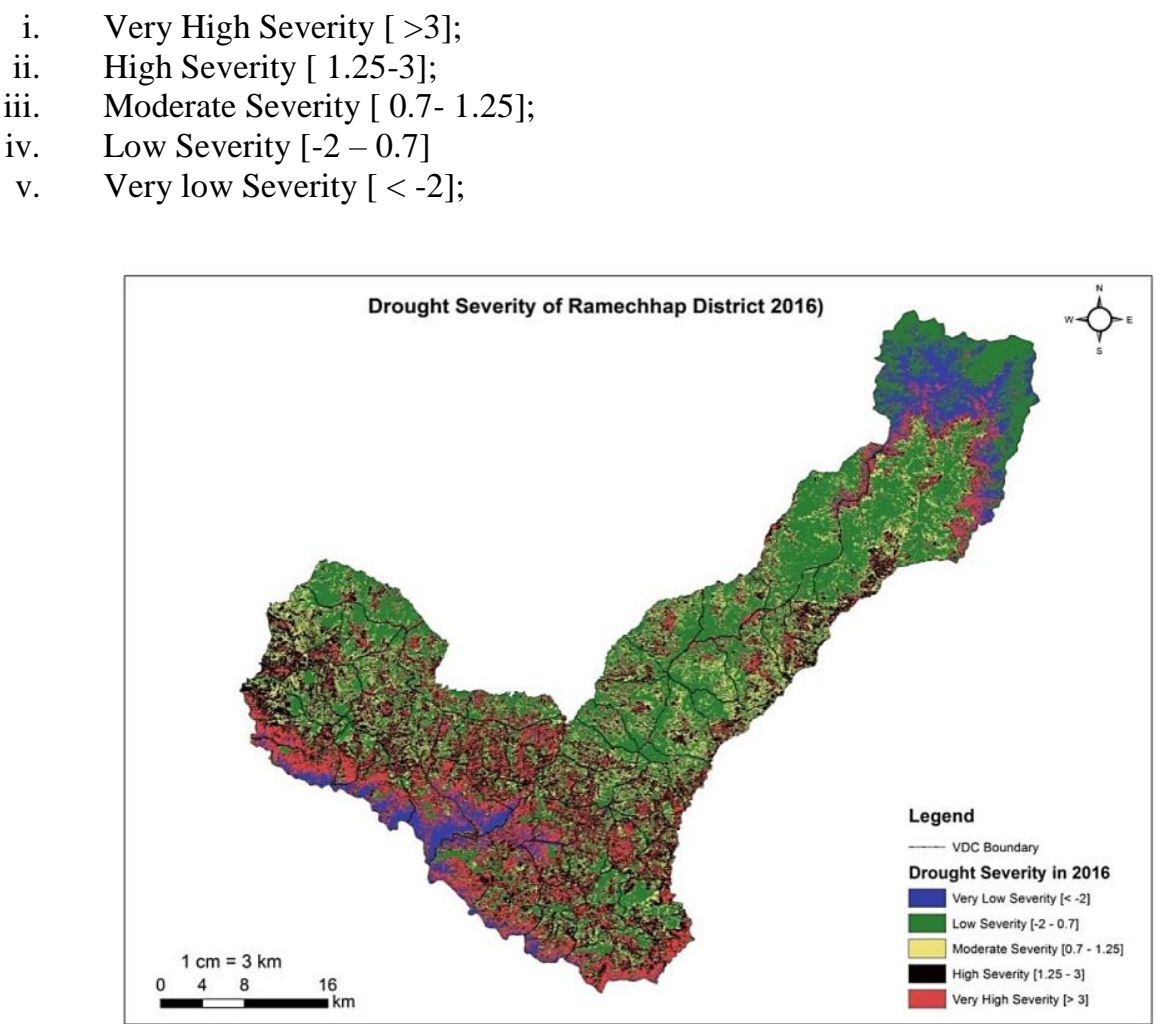

Figure 12. Drought severity map of Ramechhap District

The agricultural area from land cover was extracted and its severity was differentiated using the drought severity classes. The Agricultural Drought Severity index ranged from values less than -1.00 to values greater than 3 which were further classified using GIS. The area for each severity class was calculated and is presented in Table 3. It is found that approximately 17230.58 ha of agricultural area has high agricultural drought severity and 10132.91 ha of agricultural land have very high agricultural drought severity.

Table 3. Area of agricultural severity class

\begin{tabular}{lll}
\hline Threshold of Agriculture Severity & $\begin{array}{l}\text { Severity class of } \\
\text { Agriculture area }\end{array}$ & Total area (in Ha) \\
\hline Very High Severity [ >3] & Very high & 10132.91 \\
High Severity [ 1.25-3] & High & 17230.58 \\
Moderate Severity [ 0.7- 1.25] & Moderate & 9033.83 \\
Low Severity [-1 - 0.7] & Low & 4372.89 \\
Very low Severity [ <-1] & Very low & 979.66 \\
& Grand Total & $\mathbf{4 1 7 4 9 . 8 7}$ \\
\hline
\end{tabular}

The spatial distribution of severity of agricultural drought of Ramechhap District is shown in Figure 13. 


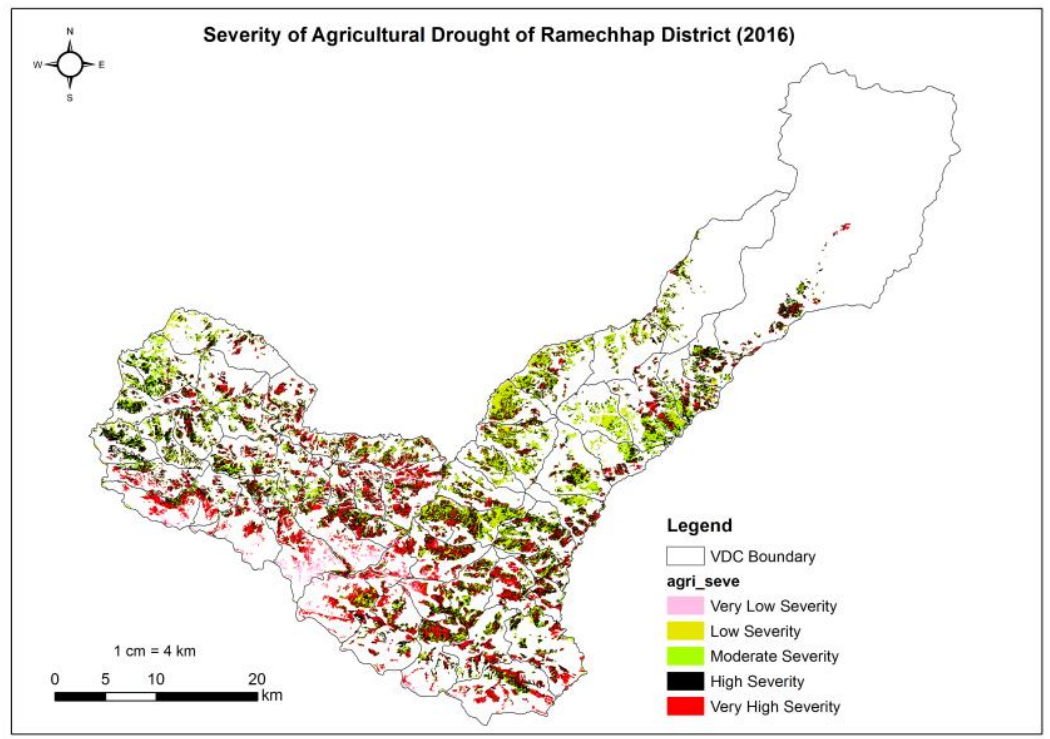

Figure 13. Agricultural drought severity map of Ramechhap District

\section{Water stressed condition}

The NDWI value ranges from -1.00 to +1.00 . The area extent was mapped to assess the water stressed area and to work out different conditions of water stresses in drought years 2006, 2009 and 2016 which is shown below on Table 4. It has been assessed that in 2009, a huge area was under highly water stressed condition in comparison to 2006 and 2016. The water stressed area was also calculated for each year and also analyzed using index as presented in Table 4.

Table 4. Area under water stress condition (in Hectare)

\begin{tabular}{|c|c|c|c|c|}
\hline Water Stress Classes & $\begin{array}{l}\text { Water Stress } \\
\text { Condition }\end{array}$ & $\begin{array}{c}\text { Area in } \\
2006 \text { (ha) }\end{array}$ & $\begin{array}{l}\text { Area in } \\
2009 \text { (ha) }\end{array}$ & $\begin{array}{c}\text { Area in } \\
2016 \text { (ha) }\end{array}$ \\
\hline $\begin{array}{l}\text { Very high Water Stressed [ } \\
-0.084]\end{array}$ & $\begin{array}{l}\text { Very highly water } \\
\text { stressed }\end{array}$ & 10096.2 & 24108.84 & 25781.94 \\
\hline High Water Stressed & High Water & & & \\
\hline [ -0.084- -0.05] & stressed & 32609.16 & 49369.76 & 24707.43 \\
\hline $\begin{array}{l}\text { Less Water Stressed [ -0.05- } \\
\text { 0] }\end{array}$ & $\begin{array}{l}\text { Less water } \\
\text { stressed }\end{array}$ & 44198.01 & 35033.04 & 33898.14 \\
\hline No Effect [ 0 -0.106] & No effect & 43364.52 & 27452.16 & 50373.27 \\
\hline \multicolumn{5}{|l|}{ Normal Condition } \\
\hline [ $0.106-0.24]$ & Normal condition & 15818.76 & 17483.85 & 18193.59 \\
\hline \multirow[t]{2}{*}{ Snow/ Glacier $[<0.24]$} & Snow/Glacier & 13045.51 & 5684.51 & 6177.79 \\
\hline & Total & 159132.16 & 159132.16 & 159132.16 \\
\hline
\end{tabular}

The spatial distribution of water stressed condition of Ramechhap District is shown in Figure 14. 


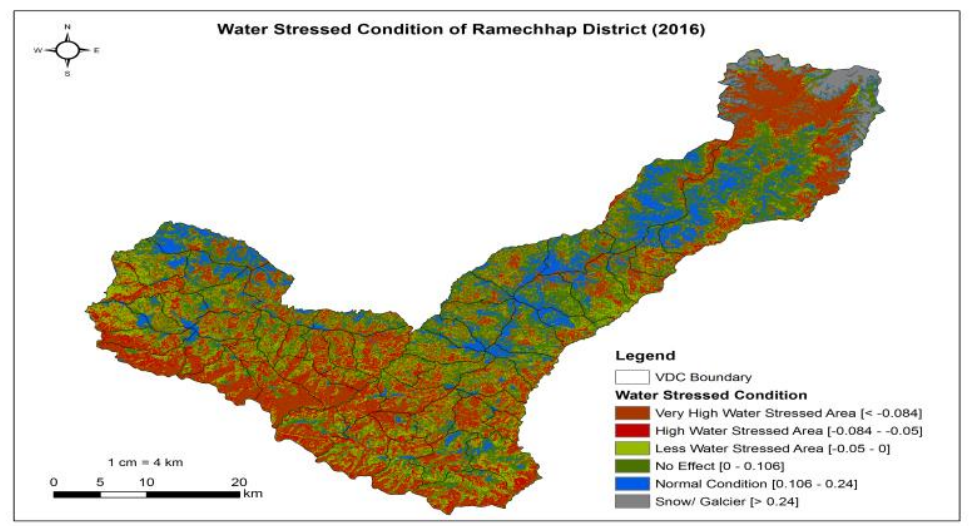

Figure 14. Water stress condition of Ramechhap District

\section{Impacts of drought on water resources leading to migration}

Due to severe drought, most of the water sources have been dried which led to increased number of seasonal migration; in some case resulting to permanent migration as well. According to the Office of District Coordination Committee, GoN, Ramechhap recorded total of 23 permanent migration in 2015/2016. Whereas 1 permanent migration in 2014/2015. Spring sources, rivers/ streams, irrigation canal and tap water in Pakarbas and Chisapani have already dried in the past 5-7 years period. From the interview with local people, it was revealed that, some of the main sources of Pakarbas which have dried in recent years are Gadapani, kakale padhero in sukulman village, Raamchemuhan in Ramche village, Sanne padhera, Munitar in Sunnegau, archalle in Gaude. Similarly, in Chisapani VDC thulopadehro, Aaitabare, ganeshthan padhera etc. which were the major water sources, which had dried. Few major streams in Chisapani have also dried in the past 5-7 years of time. In addition to this, respondent shared that one stream used to bring flood back in 5-7 years but now it has also dried completely. Due to several dry spring sources and taps, people dependent on these sources are forced to migrate. This has increased drought exposure area which has left no option other than to migrate.

\section{Impacts of drought on agricultural land leading to migration}

Due to less rainfall in the study areas, people have been practicing agriculture in rented land despite of huge area available in their native lands. As revealed from interviews with key informants, almost $75-80 \%$ populations of both study area are fully dependent on seasonal migration as an alternative income sources during off-seasonal periods. In addition, local respondents also added that 5-7 years back, there used to be lot of livestock in each house but due to drought and drying of water sources, the number of livestock rearing at the households has decreased. Since limited available water resources have brought changes in moisture and agricultural production, it resulted in to lesser production of fodder. In some cases, the farmers have to even buy fodder for their stall feeding. Livelihood dependency of most of the people residing in study area is agriculture and due to drought, they have been taking various strategies like plastic ponds, renting land, crop shifting, tunnel farming, vegetable farming, rainwater harvesting, migrating to besi during hot season. The common coping strategy of women towards agriculture in Pakarbas is the use of sukkah dhan (dry paddy) and dhulebyad (dry paddy seed bed). The common problems faced by the local farmers are poor seed 
immaturity and seed drying. Both have impact on lesser production due to incapability of the farmers to water the seeds when needed the most. Field visits in 2017 revealed that due to prolonged drought, crop yields are becoming more variable and have forced farmers to leave their land barren and result in seasonal migration. Due to absence of male members in families, there are difficulties in agricultural practices for single headed women to manage agriculture farming along with other household responsibilities. The study also revealed that they have also been using lift water for their Kitchen garden (karesabari) as well as for their livestock and goats in Chisapani VDC whilst people residing in Pakarbas VDC have to buy water for their livestock. Due to several dry spring sources and taps, people dependent on these sources are forced to migrate. This has increased drought exposure area which has left no option other than to migrate.

\section{Impact of drought on seasonal migration}

Seasonal migration is related to the agricultural cycle. For instance, there is a trend of increased frequency and duration of seasonal migration, as a result of environmental risks. Farmers of Pakarbas and Chisapani migrate to Bhaktapur District during the fallow period; people are seasonally migrating to work in brick factories in Bhaktapur District, hotels and road maintenance works etc. Recently, after the women have started living in besi (low land area), their water fetching time has saved, which is being utilized in vegetable farming. Migrants work in the brick kilns for 6 months with regular weekly payment for household expenses. Drought has led to less agricultural production (8\% of production decreased in 2014/2015 due to no rainfall (District Agriculture Development Office) due to which people have been adopting seasonal migration as a livelihood strategy. The findings of this study supports that due to less production people have been migrating to brick kilns seasonally during non-monsoon season and few people in Chisapani have also permanently migrated resulting complete land abandonment. Field visits in 2017 identified that there were few lands which were left abandoned due to lack of water.

\section{Impacts of drought to females leading to migration}

Based on the interviews with key informants, women, whose husband has migrated out in search of better life styles, face several problems like managing their farms and families, fetching drinking water, selecting appropriate varieties of seed, crop harvesting and its proper handling and storage, selling of farm products in the market. Most of the people of Ramche, Sukulman, Bhimsenthan, Jimmetar, Junre, Sunnegaun have migrated to besi (low land) of Pakarbas as water is easily available in Tamakoshi River. An assessment of field interviews, both male and female respondents in Pakarbas and male respondents in Chisapani expressed their views that drought had caused greater impact to female. It took them almost whole day for one bucket of water to be fetched from the nearby sources. In addition, female respondent also shared that to get one gagri/bucket of water they had to wake up at 1:00 AM and also even during day time they had to wait in queue. For the migrated female, it took 30-45 minutes to fill one gagri (metal vessel) and they normally spend 6 hours to fetch water. It was interesting to note that female used to go quietly to fetch water in the early morning so that no one wakes up in their neighborhood. Despite of this caution, sometimes they had to return without water. They used to have lots of disputes over the limited water at the source. Water sources had gradually dried up over the year at present all those sources have dried up which left no alternatives for them besides migrating to besi of Pakarbas.

Eighteen out of 21interviewed households during field survey of Pakarbas have migrated to besi due to water shortage and less agricultural production. The women who stayed behind 
after their husband's seasonal migration to work in brick kilns and hotels of Bhaktapur District; they are involved in small business in Khurkot market. Women have complained their difficulties of not having male member during harvesting time (12 out of 14 female headed households), problems in hiring labourers during peak cultivation and harvesting time (17 out of 21interviewed households), difficulties in adopting new machineries like hand tractor ( 9 out of 14 female households), bringing water to field from Tamakoshi River ( 9 out of 14 female households), less strength to lift water from technologies available near Tamakoshi like lift irrigation (11 out of 14 female headed households).

\section{CONCUSIONS}

Climate data recorded in hydrological station of Manthali revealed an increasing trend in temperature and number of dry months that result in decrease in total annual rainfall. Due to increase in temperature and less or no rainfall, crops like maize, paddy and wheat have been severely affected during past 10 years.

The drought exposure index in study area- Pakarbas and Chisapani were high. However, 2009 has maximum area exposed to drought and the year was recorded as one of the severe drought years according to DPR as well as from the respondents of the areas. Moreover, result of NDWI also indicated that a severe water stress in both of the study areas, the severity was high in 2009. Respondents from different villages who have migrated to besi (low land) from Pakarbas expressed very clearly that their major sources of water had gone completely and permanently dry. Maximum LST was found in 2009 which has decreased the soil moisture led to drying of maize seed preventing it from germination and reduce crop yields during 2009 .

The major reason for seasonal/intra and inter district migration is mainly attributed to insufficient and year-round sources for livelihood of the communities. Not all migrants were successful to raise their income for household but were able to minimize risks resultant of drought for their livelihoods. Therefore, seasonal migration has not only raised household income but also reduced the risks faced by households for agriculture due to extreme weather (drought) conditions or price fluctuations in the farm sector. Seasonal migration also has a direct and prominent impact on agricultural activities for women farmers during cultivation time as well as to manage their household activities simultaneously. Migration has created labor shortages in the villages during the peak agriculture practices and which expands high labor wages. Primary reasons of seasonal migration to brick kilns as well as to besi are the low agriculture production due to less or lack of rainfall and high temperature including scarcity of drinking water. Therefore, seasonal/intra migration in Ramechhap District is a common practice for diversifying the livelihood.

\section{RECOMMENDATIONS}

Both the studied areas were hit several times by drought resulting in minimal production of agriculture products for the last 10 years. Therefore, it is very important for the government bodies, local people as well as other I/NGOs to focus on water management sectors as well as drought mitigation and management strategies. 
i. District Agriculture Development Office has been promoting drought resistant crops but farmers are unaware about such types of crops availability. Therefore, it seems to have information gap among farmers and local bodies. Active awareness program should be promoted including demonstration and its impacts should be monitored as well.

ii. Hydrological and Meteorological stations should be increased for proper monitoring of climate change as it lies in rain shadow area, generalizing the climate data for whole Ramechhap District does not provide actual information.

iii. Rehabilitation and restoration of water resources is vital that will help the residents to live back to their origin village instead of living in rent and renting land for farming.

iv. Adoption of coping and level of adaptation strategies, delivering training to farmers during distributing seeds shall also be studied which could be one of aspects of decreased production.

\section{ACKNOWLWDGEMENTS}

We would like to thank International Development and Research Center (IDRC) Canada and South Asia Consortium for Interdisciplinary Water Resource Studies (SaciWATERs) for the IDRC-SAWA fellowship and research grant.

\section{REFERENCES}

Choudhary, S.S., Garg, D.P. and Ghosh D.S. (2012). Mapping of agriculture drought using remote sensing and GIS. Int. J. Sci. Eng. Technol., 1(4), 149-157.

CIAT-World Bank-UNEP. (1999). Climate Risk Index.

Climate-Data. (2016). Climate data [on line]. [Accessed on 16.07.2016]. Available at https://en.climate-data.org/location/1025394/

Erdenetuya, M., Bulgan, D. and Erdenetsetseg, B. (2011). Drought monitoring and assessment using multi satellite data in Mongolia.32 ${ }^{\text {nd }}$ Asian Conference on Remote Sensing (2011), TSI-Climate change, 978-1-61839-2. Ulaanbaatar.

Farrow, A., Larrea, C., Hyman, G. and Lema, G. (2005). Exploring the determinants of food poverty in Ecuador. Land Use Project Annual Report. Uso De La Tierra, 25-104.

GoN. (2011). Disaster Preparedness Plan, Ramechhap: District Disaster Management Committee, Ramechhap, Nepal.

GoN. (2016). Climate Portal Home, Department of Hydrology and Meteorology. [on line]. [Accessed on 12.12.2016]. Available at http://www.dhm.gov.np/dpc/

Gu. Y., Hunt. E., Wardlow B., Basara J.B., Brown J.F. and Verdin J.P. (2008). Evaluation of MODIS NDVI and NDWI for vegetation drought monitoring using Oklahoma mesonet soil moisture data. Geophys. Res. Lett., 35(22), 1-5. 
IPCC (2007) Climate Change 2007: Impacts, adaptation and vulnerability. contribution of working group II to the fourth assessment, Report of the Intergovernmental Panel on Climate Change, M.L. Parry, O.F. Canziani, J.P. Palutikof, P.J. van der Linden and C.E. Hanson, Eds., Cambridge University Press, Cambridge, UK.

JRC and IES (2011). Factsheet NDWI - Europe. Available at http://edo.jrc.ec.europa.eu/documents/factsheets/factsheet_ndwi.pdf

Karnieli , A., Agam, N, Pinker, R., Anderson, M., Imhoff, M., Gutman , G., Panov, N. and Goldberg , A. (2009). Satellite-derived drought assessment: Merits and limitations. Dahlia Greidinger International Symposium. Available at http://gwri-ic.technion.ac.il/pdf/DG/2009/3.pdf.

Kogan, F. (1997). Global drought watch from space. Bull. Am. Meteorol. Soc., 78(4), 621636.

Mehta, R.K. and Shah, S.C. (2012). Impact of climate change on water availability and food -security of Nepal. Hydro Nepal, Special Issue: Conference Proceedings, 59-63.

MODIS. (2016). MODIS. [on line]. [Accessed on 21.08.2016]. Available at https://modis.gsfc.nasa.gov.

RRC.AP. (2012). Institutional responses to local-level climate change adaptation in Nepal. Policy Research Brief No 4, Regional Resource Centre for Asia and the Pacific (RRC.AP).

Shrestha, S., Acharya, D., Shrestha, N., Adhikari, H., Bhatta and Shrestha, A. (2015). An assessment of drought in Ramechhap District, Available at

https://shyamstha.wordpress.com/2015/08/01/an-assessment-of-drought-in-ramechhapdistrict/

Shrestha, A.B., Wake, C.P., Mayewski, P.A. and Dibb, J.E. (1999). Maximum temperature trends in the Himalaya and its vicinity: An analysis based on temperature records from Nepal for the period 1971-94. University of New Hampshire Scholars' Repository, 12(9), 27752786.

Thapa, M.B. (2012). A report on: effect of climate change on vegetable seed production in some selected pockets of Nepal. Vegetable Seed Project (VSP) III Center for Environmental and Agricultural Policy Research, Extension and Development (CEAPRED), Nepal.

Thenkabail, P.S., Gamage, N. and Smakhtin, V. (2004). The use of remote sensing data for drought assessment and monitoring in Southwest Asia. International Water Management Institute Research Report, 85.

Tucker, C.J. (1979). Red and photographic infrared linear combinations for monitoring vegetation. Remote Sens. Environ., 8, 127-150. 